=技 $\quad$ 術 $=$

\title{
ガス置換包装された食肉の保存性
}

\author{
三浦和行*1 • 成田静香*1 $・$ 戸田由紀*1 $・$

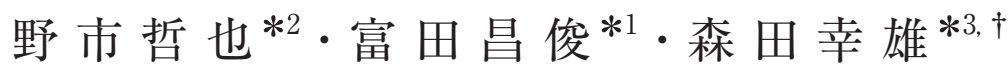 \\ (*1 スターゼン (株), *2 スターゼンミートプロセッサー (株), *3 東京家政大学)
}

(受付：平成 30 年 5 月 1 日)

（受理：平成 30 年12月19日）

\section{Conservation of Beef and Pork Using Modified Atmosphere Packaging}

\author{
Kazuyuki Miura ${ }^{* 1}$,Shizuka Narita ${ }^{* 1}$, Yuki TodA ${ }^{* 1}$, \\ Tetsuya Norchi ${ }^{* 2}$, Masatoshi Tomita ${ }^{* 1}$ and Yukio Morita ${ }^{* 3, \dagger}$ \\ (*1 Starzen Co., Ltd., Konan Bld., Konan, Minato-ku, Tokyo 108-0075) \\ ( ${ }^{* 2}$ Starzen Meat Processor Co., Ltd., Konan Midato-ku, Tokyo 108-0075) \\ (*3 Tokyo Kasei University, Kaga, Itabashi-ku, Tokyo $173-8602 ;{ }^{\dagger}$ Corresponding author)
}

食品のガス置換包装（Modified Atmosphere Packaging：以下，「MAP」と略）は食品を包装するガスを二酸 化炭素や窒素による不活性ガスや酸素などに置換して食 品の変質を抑制し, 食品本来のもつ品質を保持するもの である ${ }^{2)}$. 食品のMAPの歴史は古く，欧米ではすでに 1930年代に生肉に炭酸ガスを使用する研究が行われ, 現 在は食肉, 食肉加工品, チーズ, 水産衫り製品, パン等, さまざまな流通食品がガス置換包装されている ${ }^{11}$. MAP は $\mathrm{EU}$ 諸国，米国でも認められている1,6)。また，各種食 品の封入ガス組成を調整した製品では「封入ガス組成」 と「シールの状態の確認」はHACCPの重要管理点とし て設定したほうが良いとの論文も散見される ${ }^{3 \sim 5)}$.

しかし, 我が国では「一酸化炭素を鮮魚に使用すると 長時間, 鮮やかな色を呈し, 消費者が鮮度を誤認する恐 れがある」として問題視されたことをきっかけとして, 平成 3 年 6 月 21 日付（衛乳第 42 号, 衛化第 36 号) 拈上 び平成 6 年 9 月 22 日付 (衛乳第 141 号, 衛化第 89 号)「鮮 魚に対する食品添加物の使用について」により, 食品の 変色防止等の目的では食品に一酸化炭素を使用すること は食品衛生法第 6 条違反とすることが各自治体に通知さ れた。また，平成 12 年 8 月 23 日付 (衛化第 48 号), 地方 自治体からの疑義回答の「生鮮食品のガス充填包装」に 抏いて, 品質保持のために二酸化炭素, 窒素, 酸素を充 填することは, 食品の鮮度等について消費者の判断を誤

\footnotetext{
$\dagger$ 連絡先

*1 函108-0075 東京都港区港南2-5-7 港南ビル

*2 画108-0075 東京都港区港南 5-1-30

*3 齿173-8602 東京都板橋区加賀 1-18-1
}

らせるおそれがあると考えられるので，このような使用 がされないように指導することが望ましいと厚生労働省 は回答している。

$\mathrm{EU}$ 諸国や米国の食肉や食肉製品では, 酸素濃度 $80 \%$, 二酸化炭素濃度 $20 \%$ で包装する高濃度酸素MAPや一酸 化炭素 $0.4 \%$, 二酸化炭素 $30 \%$, 窒素 $69.6 \%$ で包装する 一酸化炭素MAPなどが使用されている ${ }^{6)}$. EU 諸国と米 国では食品の表示にMAPの表示義務はあるが封入ガス の組成の表示義務はない，筆者らは $\mathrm{EU}$ 諸国や米国に挍 いて, MAP食肉が販売されていることを店頭で数多く 見ている。 また, 食肉製造企業や食品の MAP機器メ一 カーからの聞き取りにより, 牛肉や豚肉は高濃度酸素 MAPが多く使用されている情報を得た.

そこで, 我々は高濃度酸素MAPの条件に打ける牛・ 豚のひき肉ならびにスライス肉の一般細菌数検査と官能 評価を実施した。また，家庭での食肉保存状況を考慮し て大気包装䇽よびMAP 試料を一定期間保管後に, 開封 し，開封1日後㧍よび2 日後の官能評価を実施した。

\section{材料および方法}

試料等：牛ひき肉は国産，豚ひき肉はカナダ産，牛ス ライス肉は豪州産, 豚スライス肉はカナダ産を国内の食 肉処理業許可施設でひき肉またはスライス肉にした。

MAP条件およびMAP条件の測定：オートマチックト レーシーラーはSEALPAC A10 (Sealpac International 社）を用いた。 バリア発泡トレーは中央化学(株)製，バリ アトップフィルムは四国化工(株)製を用いた。な押，バリ ア発泡トレーおよびバリアトップフィルムの酸素透過度 
は，それぞれ $8.4 \mathrm{cc} / \mathrm{m}^{2} \cdot$ day·atm, $13.6 \mathrm{cc} / \mathrm{m}^{2} \cdot$ day·atm ある。食品を入れない状態でオートマチックトレーシー ラーでMAPを行い, 包装中の酸素と二酸化炭素濃度は Checkmate 9900 (Dansensor 社) で測定した。

大気包装および MAP 試料の一般細菌数と官能評価: 各試料約 $100 \mathrm{~g}$ を MAPおよび通常大気の包装（以下, 「大気包装」と略）はオートマチックトレーシーラーで 実施後, $4 \pm 1^{\circ} \mathrm{C}$ の冷蔵庫で保存した。包装時 $(\mathrm{D}+0)$, 包装 3 日後 $(D+3)$, 包装 5 日後 $(D+5)$, 包装 7 日後 $(\mathrm{D}+7)$ ，包装 10 日後 $(\mathrm{D}+10)$ に一般細菌数を測定する とともに官能評価を実施した。一般細菌数は官能評価後 の試料 $25 \mathrm{~g}$ に $225 \mathrm{~mL}$ の滅菌PBSを加え, 1 分間スト マッカ一処理を行い試料原液とした。その試料原液およ び適宜段階希釈した 10 倍希橎液 $1 \mathrm{~mL}$ を各々 2 枚のペト リフィルム $\mathrm{AC}$ プレート $(3 \mathrm{M})$ に滴下し， $35^{\circ} \mathrm{C} ， 48$ 時間 培養した。培養後，プレート上に生育した集落を目視に て測定し，試料 $1 \mathrm{~g}$ あたりの一般細菌数を算出した。な お一条件あたり三つの試料の一般細菌数を算出し，その 対数平均值をその条件の一般細菌数とした。官能評価は 熟練した 3 名の試験者により，「期限表示のための試験 方法ガイドライン [食肉（食肉加工（半製品）を含む)] の官能検査法に従って評価した。

大気包装およびMAP 試料の開封時・開封後の官能評

価：大気包装およびMAPの D+3, D+5, D+7, D+10 の試料について，開封後前述の試験を実施し，5分間以 内に大気条件下で再度ラップにて包装し，冷蔵庫に戻し た。 その開封 1 日後および 2 日後の試料について官能評 価を実施した。

\section{成績}

大気包装およびMAP 試料中の酸素・二酸化炭素濃 度：通常の大気包装の酸素濃度は20.6 21.1\%，二酸化 炭素濃度は $0.1 \%$ であった.MAPの酸素濃度は79.3〜 $79.6 \%$ ，二酸化炭素濃度は 17.7～18.7\%であった。

大気包装およびMAPした試料の一般細菌数と官能評価

牛肉および豚肉を大気包装およびMAPした時の一般 細菌数と官能評価の結果を表 1 に示した.

牛ひき肉：実験開始時の一般細菌数は $3.1 \times 10^{5} \mathrm{CFU} / \mathrm{g}$ であった。大気包装の場合は 3 日目には $1.0 \times 10^{5} \mathrm{CFU} / \mathrm{g}$, 5 日目には $1.5 \times 10^{5} \mathrm{CFU} / \mathrm{g}, 7$ 日目には $7.1 \times 10^{6} \mathrm{CFU} / \mathrm{g}$, 10 日目には $1.5 \times 10^{8} \mathrm{CFU} / \mathrm{g}$ まで一般細菌数は増加した。 一方, MAPのものは 3 日目には $8.5 \times 10^{4} \mathrm{CFU} / \mathrm{g}, 5$ 日目 には $7.6 \times 10^{4} \mathrm{CFU} / \mathrm{g}, 7$ 日目には $1.2 \times 10^{5} \mathrm{CFU} / \mathrm{g}, 10$ 日 目には $5.4 \times 10^{4} \mathrm{CFU} / \mathrm{g}$ で，一般細菌数は実験開始時よ り低下した。大気包装試料では7日目，10日目に腐敗臭 と褐変が，MAP試料では7日目に腐敗臭が，10日目に は腐敗臭と褐変が認められた。

豚ひき肉：実験開始時の一般細菌数は $3.3 \times 10^{5} \mathrm{CFU} / \mathrm{g}$ であった。大気包装の場合は 3 日目には $9.3 \times 10^{4} \mathrm{CFU} / \mathrm{g}$, 5 日目には $1.6 \times 10^{5} \mathrm{CFU} / \mathrm{g}, 7$ 日目には $6.2 \times 10^{5} \mathrm{CFU} / \mathrm{g}$, 10 日目には $6.0 \times 10^{6} \mathrm{CFU} / \mathrm{g}$ まで一般細菌数は増加した。 一方，MAPのものは 3 日目には $1.1 \times 10^{5} \mathrm{CFU} / \mathrm{g}, 5$ 日目 には $1.5 \times 10^{5} \mathrm{CFU} / \mathrm{g}, 7$ 日目には $2.2 \times 10^{5} \mathrm{CFU} / \mathrm{g}, 10$ 日 目には $5.9 \times 10^{5} \mathrm{CFU} / \mathrm{g}$ で，実験開始時とほほ同様で あった。 大気包装試料で 10 日目から腐敗臭と褐変が認 められた。MAP試料は10日目まで異常は認められな

表1. 大気包装およびガス置換包装 (MAP) した試料の一般細菌数と官能評価

\begin{tabular}{|c|c|c|c|c|c|c|}
\hline 検体 & ガス条件 & $\mathrm{D}+0$ & $\mathrm{D}+3$ & $\mathrm{D}+5$ & $\mathrm{D}+7$ & $\mathrm{D}+10$ \\
\hline \multirow{2}{*}{ 牛ひき肉 } & 大気包装 & \multirow{2}{*}{$\begin{array}{c}3.1 \times 10^{5} \\
\text { 異常なし1) }\end{array}$} & $\begin{array}{l}1.0 \times 10^{5} \\
\text { 異常なし }\end{array}$ & $\begin{array}{l}1.5 \times 10^{5} \\
\text { 異常なし }\end{array}$ & $\begin{array}{c}7.1 \times 10^{6} \\
\text { 腐敗臭あり } \\
\text { 褐変あり }\end{array}$ & $\begin{array}{c}1.5 \times 10^{8} \\
\text { 腐敗臭あり } \\
\text { 褐変あり }\end{array}$ \\
\hline & MAP & & $\begin{array}{l}8.5 \times 10^{4} \\
\text { 異常なし }\end{array}$ & $\begin{array}{l}7.6 \times 10^{4} \\
\text { 異常なし }\end{array}$ & $\begin{array}{c}1.2 \times 10^{5} \\
\text { 腐敗臭あり }\end{array}$ & $\begin{array}{c}5.4 \times 10^{4} \\
\text { 腐敗臭あり } \\
\text { 褐変あり }\end{array}$ \\
\hline \multirow[t]{2}{*}{ 豚ひき肉 } & 大気包装 & \multirow{2}{*}{$\begin{array}{l}3.3 \times 10^{5} \\
\text { 異常なし }\end{array}$} & $\begin{array}{l}9.3 \times 10^{4} \\
\text { 異常なし }\end{array}$ & $\begin{array}{l}1.6 \times 10^{5} \\
\text { 異常なし }\end{array}$ & $\begin{array}{l}6.2 \times 10^{5} \\
\text { 異常なし }\end{array}$ & $\begin{array}{c}6.0 \times 10^{6} \\
\text { 腐敗臭あり } \\
\text { 褐変あり }\end{array}$ \\
\hline & MAP & & $\begin{array}{l}1.1 \times 10^{5} \\
\text { 異常なし }\end{array}$ & $\begin{array}{l}1.5 \times 10^{5} \\
\text { 異常なし }\end{array}$ & $\begin{array}{l}2.2 \times 10^{5} \\
\text { 異常なし }\end{array}$ & $\begin{array}{l}5.9 \times 10^{5} \\
\text { 異常なし }\end{array}$ \\
\hline \multirow{2}{*}{ 牛スライス肉 } & 大気包装 & \multirow{2}{*}{$\begin{array}{l}1.6 \times 10^{2} \\
\text { 異常なし }\end{array}$} & $\begin{array}{c}3.7 \\
\text { 異常なし }\end{array}$ & $\begin{array}{r}3.2 \times 10 \\
\text { 異常なし }\end{array}$ & $\begin{array}{l}3.0 \times 10^{3} \\
\text { 異常なし }\end{array}$ & $\begin{array}{l}8.9 \times 10^{4} \\
\text { 異常なし }\end{array}$ \\
\hline & MAP & & $\begin{array}{r}4.1 \times 10 \\
\text { 異常なし }\end{array}$ & $\begin{array}{l}1.2 \times 10 \\
\text { 異常なし }\end{array}$ & $\begin{array}{r}8.5 \times 10 \\
\text { 異常なし }\end{array}$ & $\begin{array}{l}1.4 \times 10^{4} \\
\text { 異常なし }\end{array}$ \\
\hline \multirow{2}{*}{ 豚スライス肉 } & 大気包装 & \multirow{2}{*}{$\begin{array}{l}1.4 \times 10^{2} \\
\text { 異常なし }\end{array}$} & $\begin{array}{l}3.0 \times 10^{2} \\
\text { 異常なし }\end{array}$ & $\begin{array}{l}8.7 \times 10^{2} \\
\text { 異常なし }\end{array}$ & $\begin{array}{r}1.4 \times 10^{4} \\
\text { 褐変あり }\end{array}$ & $\begin{array}{r}1.3 \times 10^{6} \\
\text { 褐変あり }\end{array}$ \\
\hline & MAP & & $\begin{array}{l}1.7 \times 10^{2} \\
\text { 異常なし }\end{array}$ & $\begin{array}{l}1.4 \times 10^{2} \\
\text { 異常なし }\end{array}$ & $\begin{array}{l}2.6 \times 10^{2} \\
\text { 異常なし }\end{array}$ & $\begin{array}{l}1.1 \times 10^{2} \\
\text { 異常なし }\end{array}$ \\
\hline
\end{tabular}

1）上段は, 一条件あたり三つの試料の一般細菌数を算出し，その対数平均值をその条件の一般細菌数 $(\mathrm{CFU} / \mathrm{g})$ とした。 下段は, 官能評価結果，背後が色付は官能評価によって異常を示したもの．期限表示のための試験方法ガイドライン［食肉（食肉加工（半 製品）を含む)］の官能検査法の「外観（ネト, 発泡, カビ, 乾燥)」,「ドリップ」についてはすべての観察期間で異常を認めず. 
かった．豚ひき肉では 10 日目に官能評価結果が異なり， 大気包装試料に比べMAP試料の方が保存性が向上し た。

牛スライス肉: 実験開始時の一般細菌数は $1.6 \times$ $10^{2} \mathrm{CFU} / \mathrm{g}$ であった。 大気包装の場合は3日目には $3.7 \mathrm{CFU} / \mathrm{g}, 5$ 日目には $3.2 \times 10 \mathrm{CFU} / \mathrm{g}, 7$ 日目には $3.0 \times$ $10^{3} \mathrm{CFU} / \mathrm{g}, 10$ 日目には $8.9 \times 10^{4} \mathrm{CFU} / \mathrm{g}$ であり,一度 一般細菌数は減少したが7日目から増加した。一方, $\mathrm{MAP}$ ののは 3 日目には $4.1 \times 10 \mathrm{CFU} / \mathrm{g}, 5$ 日目には 1.2 $\times 10 \mathrm{CFU} / \mathrm{g}, 7$ 日目には $8.5 \times 10 \mathrm{CFU} / \mathrm{g}, 10$ 日目には $1.4 \times 10^{4} \mathrm{CFU} / \mathrm{g}$ で，一般細菌数は 7 日目まではほぼ横ば いであったが10日目に増加した．MAPおよび大気包装 試料ともに10日目まで異常は認められなかった.

豚スライス肉：実験開始時の一般細菌数は $1.4 \times$ $10^{2} \mathrm{CFU} / \mathrm{g}$ であった。 大気包装の場合は 3 日目には $3.0 \times$ $10^{2} \mathrm{CFU} / \mathrm{g}, 5$ 日目には $8.7 \times 10^{2} \mathrm{CFU} / \mathrm{g}, 7$ 日目には 1.4

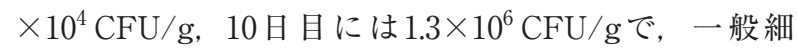
菌数は 5 日目まではほぼ横ばいであったが7日目以降に 増加した。一方, MAPのものは3日目には $1.7 \times$ $10^{2} \mathrm{CFU} / \mathrm{g}, 5$ 日目には $1.4 \times 10^{2} \mathrm{CFU} / \mathrm{g}, 7$ 日目には2.6 $\times 10^{2} \mathrm{CFU} / \mathrm{g}, 10$ 日目には $1.1 \times 10^{2} \mathrm{CFU} / \mathrm{g}$ で，一般細 菌数は実験開始時とほぼ同様であった。 大気包装試料で 7 日目から褐変が認められた。 MAP試料は10日目まで 異常は認められなかった。豚スライス肉では7日目以降 に官能評価結果が異なり，大気包装試料に比べMAP試 料の方が保存性が向上した。

\section{大気包装およびMAPした試料の開封時 ·開封後の官 能評価}

牛肉および豚肉を大気包装およびMAPした試料を開 封した時ならびに開封後の官能評価の結果を表 2 に示し た.

牛ひき肉：大気包装およびMAPともに 3 日目の試料 は開封時, 開封 1 日後, 開封 2 日後ともに異常は無かっ た. 5 日目の試料の開封後 2 日では大気包装およびMAP ともに腐敗臭と褐変が認められた。7日目以降の試料は 異常が認められた.

豚ひき肉：MAP試料は調査したすべての条件におい て異常は認められなかった。 大気包装の 3 日目ならびに 5 日目の試料は開封時, 開封 1 日後, 開封 2 日後ともに 異常は無かった. 7 日目の試料では開封時, 開封 1 日後 は異常は無かったが, 開封 2 日後は腐敗臭と褐変が認め られた. 10 日目の試料では開封時, 開封 1 日後, 開封 2 日後ともに腐敗臭と褐変を認めた。7日目の試料の開封 2 日後では官能評価結果が異なり, 大気包装試料に比べ MAP試料の方が保存性が向上していた，10日目の試料 ではMAP試料の開封 2 日後でも異常は無く, MAP試料 は開封後においても保存性が高いと思われた。

牛スライス肉：大気包装試料および MAP 試料ともに 調査したすべての条件において異常は認められなかっ た。
豚スライス肉：MAP試料は調査したすべての条件に おいて異常は認められ無かった。 大気包装の3日目なら びに 5 日目の試料は開封時, 開封 1 日後, 開封 2 日後と もに異常は無かった。 7 日目の試料では開封時, 開封 1 日後は褐変あり, 開封 2 日後は腐敗臭と褐変を認めた. 同様に, 大気包装 10 日目の試料においても, 開封時, 開封 1 日後は褐変あり, 開封 2 日後は腐敗臭と褐変を認 めた. 7 日目および 10 日目の試料ではMAP試料の開封 2 日後でも異常は無く, MAP試料は開封後においても 保存性が高いと思われた。

\section{考察}

EU諸国，米国等では食肉への MAPは一般化してい る. ドイツ連邦リスク評価研究所は「高酸素ガス包装の 肉に関する FAQ」を 2010 (平成 22) 年 8 月 11 日に公表し ている（日本語訳は食品安全委員会ホームページ食品安 全関係情報詳細 syu03190680314に掲載)。それによる と, ドイツ連邦ではスーパーのパック入り生肉の約 $90 \%$ MAPであること, MAPは化学反応, 微生物お よび酵素による劣化を抑制するとされており，生の豚肉 や牛肉の包装によく使用されるのは高酸素ガスであるこ と, 鮮やかな肉の赤色を長期間保つためであること, MAPされた生肉の日持ちはよくなるが, 適切な温度で 冷蔵し, 開封後は数日以内に消費するよう留意すること などが記述されている，そこで，MAP試料と通常の大 気包装試料について, 一般細菌数の変化と腐敗臭や色調 の変化について検討した.

今回実施したMAP（二酸化炭素濃度約 $20 \%$, 酸素濃 度 $80 \%$ ）試料と大気包装試料において, D+5, D+7, $\mathrm{D}+10$ のすべての供試試料で MAPの方が大気包装のも のに比べて一般細菌数が低值であった．また，牛ひき肉 および牛スライス肉では大気包装と MAPで官能評価は 同様であった。しかし，豚ひき肉では $\mathrm{D}+10$, 豚スライ ス肉では $\mathrm{D}+7$ と $\mathrm{D}+10$ で大気包装試料と MAP 試料で官 能評価が異なり, MAP試料では異常なしであった。 MAPすると一般細菌数が低值に抑えられる試料が多 く, さらに, 官能評価の結果から豚ひき肉と豚スライス 肉では消費期限が伸びる効果があると思われた。

家庭での食肉保存状況を考慮して, 大気包装および MAP 試料を開封し, 開封 1 日後, 開封 2 日後について 官能評価を実施したところ，牛ひき肉ならびに牛スライ ス肉では大気包装とMAPで官能評価は同様であった。 しかし，豚ひき肉では $\mathrm{D}+7$ の開封 2 日後, $\mathrm{D}+10$ の開封 時, 開封 1 日後, 開封 2 日後において, 豚スライス肉で は D+7, D+10の開封時, 開封 1 日後, 開封 2 日後で大 気包装試料とMAP試料との間で官能評価が異なり, MAP試料では異常なしであった. 豚ひき肉と豚スライ ス肉ではMAPを実施すると官能評価の結果から消費期 限が伸びる効果があると思われた。

MAPについては, 平成 12 年 8 月 23 日付（衛化第 48 
表2. 大気包装およびガス置換包装(MAP)した試料の開封時・開封後の官能評価

\begin{tabular}{|c|c|c|c|c|c|}
\hline 検体 & 経過日 & ガス条件 & 開封時 & 開封 1 日後 & 開封 2 日後 \\
\hline \multirow{8}{*}{ 牛ひき肉 } & \multirow{2}{*}{$\mathrm{D}+3$} & 大気包装 & 異常なし & 異常なし & 異常なし \\
\hline & & MAP & 異常なし & 異常なし & 異常なし \\
\hline & \multirow{2}{*}{$\mathrm{D}+5$} & 大気包装 & 異常なし & 異常なし & $\begin{array}{c}\text { 腐敗臭あり } \\
\text { 褐変あり }\end{array}$ \\
\hline & & MAP & 異常なし & 異常なし & $\begin{array}{c}\text { 腐敗臭あり } \\
\text { 褐変あり }\end{array}$ \\
\hline & \multirow{2}{*}{$\mathrm{D}+7$} & 大気包装 & $\begin{array}{c}\text { 腐敗臭あり } \\
\text { 褐変あり }\end{array}$ & $\begin{array}{c}\text { 腐敗臭あり } \\
\text { 褐変あり }\end{array}$ & $\begin{array}{c}\text { 腐敗臭あり } \\
\text { 褐変あり }\end{array}$ \\
\hline & & MAP & 腐敗臭あり & $\begin{array}{c}\text { 腐敗臭あり } \\
\text { 褐変あり }\end{array}$ & $\begin{array}{c}\text { 腐敗臭あり } \\
\text { 褐変あり }\end{array}$ \\
\hline & \multirow{2}{*}{$\mathrm{D}+10$} & 大気包装 & $\begin{array}{c}\text { 腐敗臭あり } \\
\text { 褐変あり }\end{array}$ & $\begin{array}{c}\text { 腐敗臭あり } \\
\text { 褐変あり }\end{array}$ & $\begin{array}{c}\text { 腐敗臭あり } \\
\text { 褐変あり }\end{array}$ \\
\hline & & MAP & $\begin{array}{c}\text { 腐敗臭あり } \\
\text { 褐変あり }\end{array}$ & $\begin{array}{c}\text { 腐敗臭あり } \\
\text { 褐変あり }\end{array}$ & $\begin{array}{c}\text { 腐敗臭あり } \\
\text { 褐変あり }\end{array}$ \\
\hline \multirow{8}{*}{ 豚ひき肉 } & \multirow{2}{*}{$\mathrm{D}+3$} & 大気包装 & 異常なし & 異常なし & 異常なし \\
\hline & & MAP & 異常なし & 異常なし & 異常なし \\
\hline & \multirow{2}{*}{$\mathrm{D}+5$} & 大気包装 & 異常なし & 異常なし & 異常なし \\
\hline & & MAP & 異常なし & 異常なし & 異常なし \\
\hline & \multirow[t]{2}{*}{$\mathrm{D}+7$} & 大気包装 & 異常なし & 異常なし & $\begin{array}{c}\text { 腐敗臭あり } \\
\text { 褐変あり }\end{array}$ \\
\hline & & MAP & 異常なし & 異常なし & 異常なし \\
\hline & \multirow{2}{*}{$\mathrm{D}+10$} & 大気包装 & $\begin{array}{c}\text { 腐敗臭あり } \\
\text { 褐変あり }\end{array}$ & $\begin{array}{c}\text { 腐敗臭あり } \\
\text { 褐変あり }\end{array}$ & $\begin{array}{c}\text { 腐敗臭あり } \\
\text { 褐変あり }\end{array}$ \\
\hline & & MAP & 異常なし & 異常なし & 異常なし \\
\hline \multirow{8}{*}{ 牛スライス肉 } & \multirow{2}{*}{$\mathrm{D}+3$} & 大気包装 & 異常なし & 異常なし & 異常なし \\
\hline & & MAP & 異常なし & 異常なし & 異常なし \\
\hline & \multirow{2}{*}{$\mathrm{D}+5$} & 大気包装 & 異常なし & 異常なし & 異常なし \\
\hline & & MAP & 異常なし & 異常なし & 異常なし \\
\hline & \multirow{2}{*}{$\mathrm{D}+7$} & 大気包装 & 異常なし & 異常なし & 異常なし \\
\hline & & MAP & 異常なし & 異常なし & 異常なし \\
\hline & \multirow{2}{*}{$\mathrm{D}+10$} & 大気包装 & 異常なし & 異常なし & 異常なし \\
\hline & & MAP & 異常なし & 異常なし & 異常なし \\
\hline \multirow{8}{*}{ 豚スライス肉 } & \multirow{2}{*}{$\mathrm{D}+3$} & 大気包装 & 異常なし & 異常なし & 異常なし \\
\hline & & MAP & 異常なし & 異常なし & 異常なし \\
\hline & \multirow{2}{*}{$\mathrm{D}+5$} & 大気包装 & 異常なし & 異常なし & 異常なし \\
\hline & & MAP & 異常なし & 異常なし & 異常なし \\
\hline & \multirow[t]{2}{*}{$\mathrm{D}+7$} & 大気包装 & 褐変あり & 褐変あり & $\begin{array}{c}\text { 腐敗臭あり } \\
\text { 褐変あり }\end{array}$ \\
\hline & & MAP & 異常なし & 異常なし & 異常なし \\
\hline & \multirow[t]{2}{*}{$\mathrm{D}+10$} & 大気包装 & 褐変あり & 褐変あり & $\begin{array}{c}\text { 腐敗臭あり } \\
\text { 褐変あり }\end{array}$ \\
\hline & & MAP & 異常なし & 異常なし & 異常なし \\
\hline
\end{tabular}

背後が色付は官能評価によって異常を示したもの．期限表示のための試験方法ガイドライン［食肉（食肉加工（半製品）を含 む)］の官能検査法の「外観（ネト，発泡，カビ，乾燥）」，「ドリップ」についてはすべての観察期間で異常を認めず. 
号）の地方自治体からの疑義回答が公表される前に, 荻 原ら ${ }^{2)}$ は肉の保存には二酸化炭素と酸素の混合比 (30 $70 \% \mathrm{CO}_{2}: 70$ 30\% $\mathrm{O}_{2}$ ) が良好であることを報告してい る.

我が国ではMAPを認めておらず，EU諸国や米国と 異なった行政指導をしている。一方, 我が国は 1 年間 632万トンの食品を廃棄していることから, 消費者庁で は「食べもののムダをなくそうプロジェクト」(http:// www.caa.go.jp/policies/policy/consumer_policy/infor mation/food_loss/), 農林水産省では「食品ロスの削減 · 食品廃棄物の発生抑制」(http://www.maff.go.jp/j/shoku san/recycle/syoku_loss/index.html)等を実施している. また，環境省等も食品ロスを減らすための取り組みを実 施している.

本実験では，一般細菌数だけの知見であるが，牛豚ひ き肉, 牛豚スライス肉の一般細菌数は MAP 試料の方 が，大気包装試料よりも低值を示すことを証明した。ま た，牛ひき肉，牛スライス肉についてはMAP試料と大 気包装試料の官能評価結果は同様であったが，豚ひき肉 と豚スライス肉の MAP試料では腐敗臭や褐変が抑制さ れた。 今後, 病原細菌であるリステリア, サルモネラ, カンピロバクター等の MAP 試料中の増殖性について詳 細なデー夕を得ることが必要と思われるが, 国際的食品 規格のハーモナイゼーションや食品衛生学の観点から も，我々は世界中で用いられているMAPを我が国も認 可・普及してもよいのではないかと思っている。また, MAPを普及することで，食品口スを若干でも軽減する 可能性もあると思っている。

\section{文献}

1) Cutter, C. N.: Microbial control by packaging: a review. Crit. Rev. Food Sci. Nutr., 42, 151-161 (2002).

2）荻原清和，蟹江 誠，矢野信禮，春田三佐夫：ガス置換 包装における二酸化炭素, 酸素, 及び混合ガスが豚挽き 肉の微生物叢並びに品質に及ぼす影響. 日本食品衛生学 会誌, 36, 252-262 (1995).

3) Nørrung, B., Andersen, J. K. and Schlundt, J.: Incidence and control of Listeria monocytogenes in foods in Denmark. Int. J. Food Microbiol., 53, 195-203 (1999).

4) Rudi, K., Maugesten, T., Hannevik, S. E. and Nissen, H.: Explorative multivariate analyses of 16S rRNA gene data from microbial communities in modified-atmosphere-packed salmon and coalfish. Appl. Environ. Microbiol., 70, 5010-5018 (2004).

5) Silva, F., Domingues, F. C. and Nerín, C.: Trends in microbial control techniques for poultry products. Crit. Rev. Food Sci. Nutr., 58, 591-609 (2018).

6) Yang, X., Wu, S., Hopkins, D. L., Liang, R., Zhu, L., et al.: Proteomic analysis to investigate color changes of chilled beef longissimus steaks held under carbon monoxide and high oxygen packaging. Meat Sci., 142, 23-31 (2018). 